\title{
The alpha cell response to glucose change during perfusion of anti-insulin serum in pancreas isolated from normal rats
}

\author{
H. Maruyama, M. Tominaga, G. Bolli, L. Orci and R.H.Unger*
}

The Center for Diabetes Research of The University of Texas Health Science Center, Veterans Administration Medical Center, Dallas, Texas, USA; The Institute of Histology and Embryology, University of Geneva School of Medicine, Geneva, Switzerland; The University of Perugia School of Medicine, Perugia, Italy

\begin{abstract}
Summary. To determine the effect of neutralization of endogenous insulin upon the glucagon response to a rise and fall of glucose concentration, pancreata isolated from normal rats were perfused with either a potent anti-pork insulin guinea pig serum or a nonimmune guinea pig serum for $30 \mathrm{~min}$. During this period glucose concentration was changed from $100 \mathrm{mg} / \mathrm{dl}$ to either 130,180 or $80 \mathrm{mg} / \mathrm{dl}$ for $10 \mathrm{~min}$. Antiserum perfusion at $100 \mathrm{mg} / \mathrm{dl}$ caused an approximately two-fold increase in glucagon which was not suppressed by an increase in glucose concentration to either 130 or $180 \mathrm{mg} / \mathrm{dl}$, although glucagon secretion was significantly suppressed in the control experiments in which nonimmune serum was perfused. However, the $0.38 \pm 0.21 \mathrm{ng} / \mathrm{min}$ rise in glucagon secretion in response
\end{abstract}

to a reduction in glucose concentration to $80 \mathrm{mg} / \mathrm{dl}$ in the control experiments was not abolished by antiserum perfusion but, instead, was enhanced $(2.66 \pm 0.60 \mathrm{ng} / \mathrm{min})$. These findings suggest that insulin may be required for glucose-mediated suppression of glucagon in the isolated pancreas of normal rats but not for stimulation of glucagon secretion by mild glucopenia. Alternatively, neutralization of insulin-mediated release-inhibition of glucagon secretion may simply have altered alpha cell responsiveness in a direction that desensitized it nonspecifically to suppression and sensitized it to stimulation.

Key words: Alpha cells, glucagon, anti-insulin serum.
Recent studies in isolated pancreata of normal rats suggest that endogenous insulin passing through the islet microcirculation exerts a constant tonic restraining influence upon basal glucagon secretion during euglycaemia [1]. However, it is not known if, in addition, changes in insulin secretion mediate alpha cell responses to acute changes in glucose concentration, as might be inferred from the fact that the glucagon response to hyper- and hypoglycaemia disappears following spontaneous or experimental destruction of the $\mathrm{B}$ cells of the islets of Langerhans [2-5]. However, such functional deficits in diabetic alpha cells could just as well be the consequence of other factors such as postinflammatory changes in the islet tissue or of the antecedent hyperglycaemia [6-8] as of the loss of endogenous insulin. Therefore, the present study was designed to assess the role of insulin in the glucagon response of normal alpha cells to glycaemic change during acute in vitro insulin deficiency induced with neutralizing antiinsulin serum in normal rat islets, thereby eliminating antecedent hyperglycaemia as a possible variable.

\footnotetext{
* Senior Medical Investigator, Dallas Veterans Administration
}

\section{Materials and methods}

Pancreata of 300-400 g male Long-Evans rats were isolated and perfused using the methods of Fanska and Grodsky [9] with modifications as previously described [10]. The perfusate contained $10 \mathrm{mmol}$ arginine $\mathrm{HCl}$, a standard practice designed to maintain high baseline glucagon secretion. Glucose concentration was maintained at $100 \mathrm{mg} / \mathrm{dl}$ for the initial $21 \mathrm{~min}$, changed to $130,180 \mathrm{or} 80 \mathrm{mg} / \mathrm{dl}$ for $10 \mathrm{~min}$ and returned to $100 \mathrm{mg} / \mathrm{dl}$ for the final $19 \mathrm{~min}$. The reduction in glucose (from 100 to $80 \mathrm{mg} / \mathrm{dl}$ ) was kept within the physiologic range of glycaemia because of previous evidence that the glucagon response to more profound glucopenia is mediated largely by release of catecholamines [10]. From 11 to $40 \mathrm{~min}$ after the start of the perfusion, $0.1 \mathrm{ml} / \mathrm{min}$ of undiluted guinea pig anti-porcine insulin serum (MilesYeda lot GP-29) or of a normal guinea pig serum (Miles lot NGP-28) was added via a sidearm.

IRG was assayed by a previously described method using $30 \mathrm{~K}$ antiserum [11]. Insulin was measured by the Herbert modification [12] of the method of Yalow and Berson [13]. Free insulin determinations could not be made in perfusate specimens collected during antiserum perfusion because of an extraordinarily high concentration of antibodies which could not be eliminated despite repeated polyethylene glycol treatment [1]. Antiserum GP-29 contained $139 \mathrm{pg} / \mathrm{ml}$ immunoreactive glucagon (IRG) and NGP-28 contained $102 \mathrm{pg} / \mathrm{ml} \mathrm{IRG}$ and $3 \mu \mathrm{U} / \mathrm{ml}$ IRI. All data were expressed as the mean \pm SEM. Statistical significance was calculated using the paired Student's t-test. Glueagon secretion rate was calculated by averaging the mean of glucagon determinations for a given period and multiplying by the flow rate for the period. 

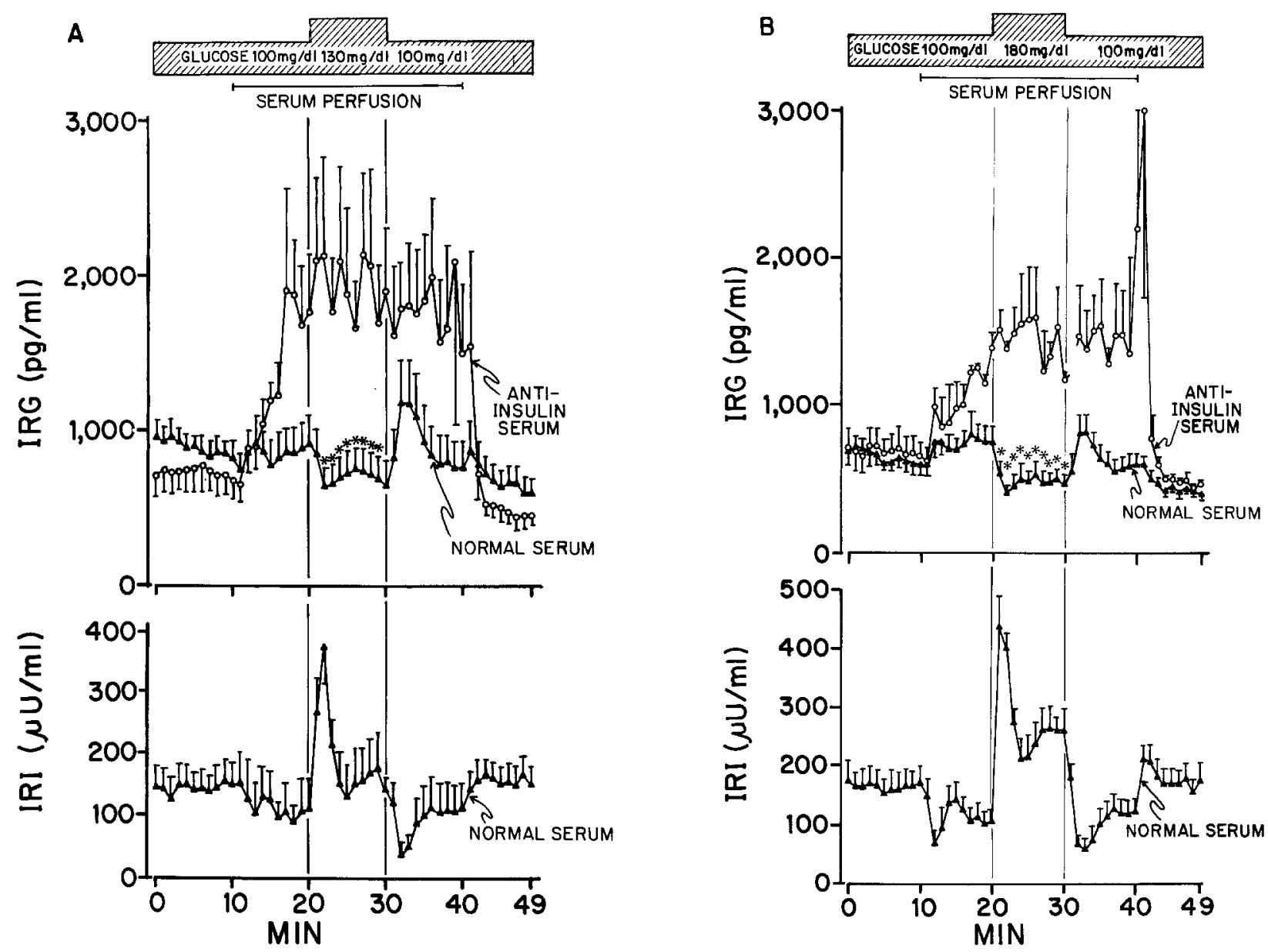

Fig. 1. A The effect of an increase in perfusate glucose concentration from $100 \mathrm{mg} / \mathrm{dl}$ to $130 \mathrm{mg} / \mathrm{dl}$ during the perfusion of either anti-pork insulin guinea pig antiserum $(n=5)$ or nonimmune guinea pig serum $(n=7)$ in pancreata isolated from normal rats. Perfusate contained $10 \mathrm{mmol}$ arginine. B The effect of an increase in perfusate glucose concentration from $100 \mathrm{mg} / \mathrm{dl}$ to $180 \mathrm{mg} / \mathrm{dl}$ during the perfusion of either anti-pork insulin guinea pig antiserum $(n=3)$ or nonimmune guinea pig serum $(n=5)$. Insulin measurements were not performed in perfusate specimens containing antiserum. Asterisks indicate significant change in glucagon compared with the baseline value $(p<0.05)$

\section{Results}

The effect of an increase in glucose concentration upon glucagon secretion by the normal rat pancreas in the presence and absence of anti-insulin serum

In control experiments in which nonimmune guinea pig serum was perfused, an increase in glucose concentration from $100 \mathrm{mg} / \mathrm{dl}$ to 130 or to $180 \mathrm{mg} / \mathrm{dl}$ for $10 \mathrm{~min}$ elicited a significant reduction of glucagon secretion at almost all time points $(p<0.05)$ (Fig. 1). The glucagon secretion rate during the $10 \mathrm{~min}$ was significantly below the rate observed in both the initial and final $10-\mathrm{min}$ periods of perfusion at $100 \mathrm{mg} / \mathrm{dl}(p<0.01)$ (Tables $1 \mathrm{~B}$, C). Upon restoring the perfusate glucose concentration of the $100 \mathrm{mg} / \mathrm{dl}$ level, a modest and transient increase in glucagon above its original value was observed (Fig. 1). Insulin, which for unexplained reasons was significantly suppressed during perfusion of nonimmune serum, rose in the familiar biphasic pattern when glucose concentration was increased.
In experiments in which guinea pig anti-pork insulin antiserum was perfused, a prompt two-fold rise in glucagon occurred as previously reported [1]. In this setting an increase in perfusate glucose concentration from $100 \mathrm{mg} / \mathrm{dl}$ to 130 or to $180 \mathrm{mg} / \mathrm{dl}$ (Fig.1) failed to reduce the glucagon secretion rate significantly below either the preceding or subsequent $100 \mathrm{mg} / \mathrm{dl}$ perfusion periods (Table $1 \mathrm{~B}$ and $\mathrm{C}$ ).

\section{The effects of a reduction of perfusate glucose concentration on the glucagon response of the normal rat pancreas in the presence and absence of anti-insulin serum}

To determine the role of endogenous insulin within the islets in the stimulation of glucagon secretion by glucopenia, the concentration in the perfusate was reduced from $100 \mathrm{mg} / \mathrm{dl}$ to $80 \mathrm{mg} / \mathrm{dl}$ for $10 \mathrm{~min}$ during a $30-\mathrm{min}$ perfusion of either anti-insulin or nonimmune guinea pig serum.

During perfusion with nonimmune serum, the slight glucopenia elicited a small rise in glucagon that was sig- 
Table 1. Effect of a change in perfusate glucose concentration on the rate of glucagon secretion by isolated pancreata from normal rats during perfusion of non-immune or anti-insulin guinea pig serum

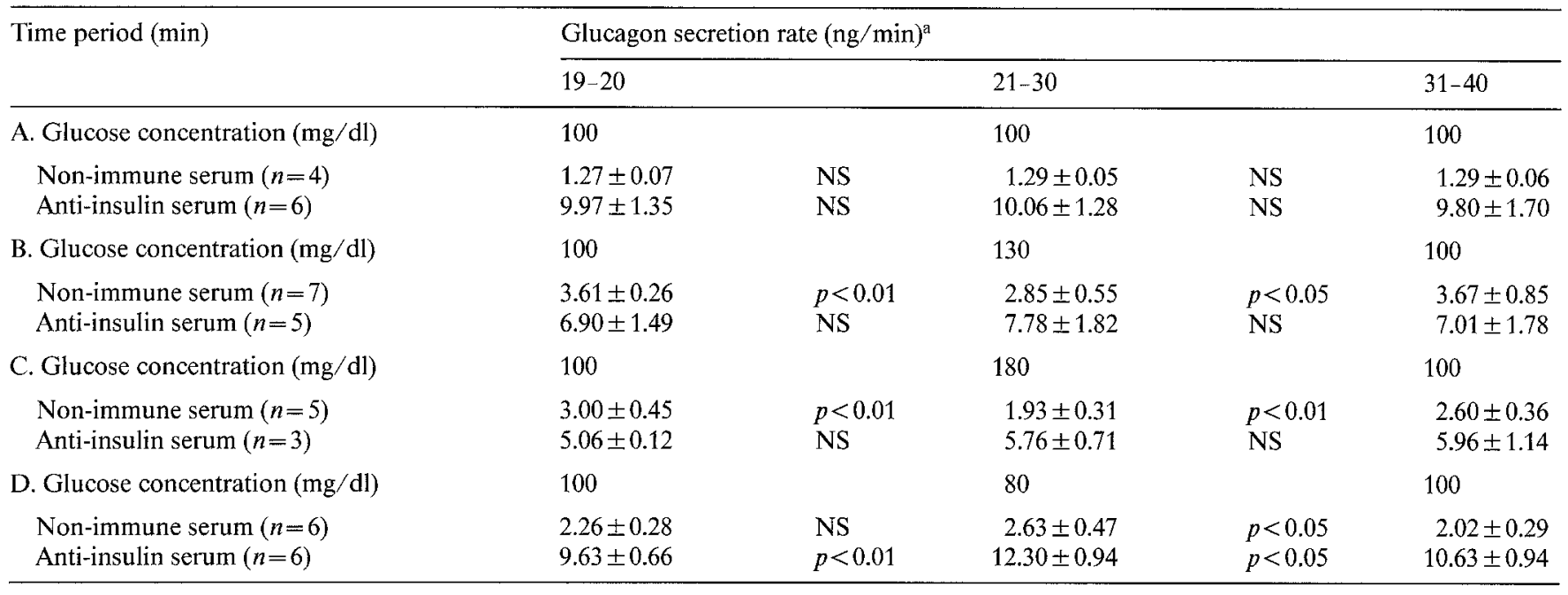

a Calculation based on mean of glucagon levels at all time points within the specified time period multiplied by the flow rate. Mean \pm SEM

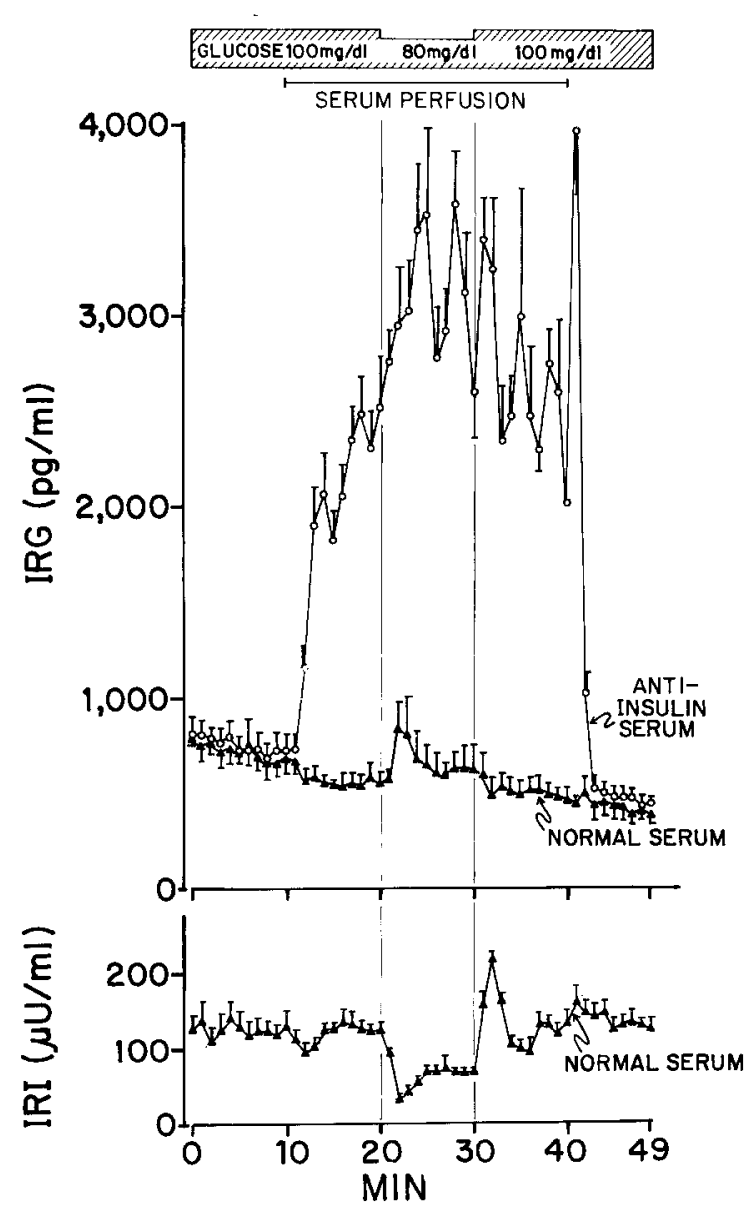

Fig. 2. The effect of a small reduction in perfusate glucose concentration upon glucagon secretion during the perfusion of either anti-pork insulin guinea pig antiserum ( $n=6$ ) or nonimmune guinea pig serum in pancreata isolated from normal rats $(n=6)$. Perfusate contained $10 \mathrm{mmol}$ arginine. Insulin measurements were not performed in perfusate specimens containing antiserum. Asterisks indicate significant change in glucagon compared with the baseline value $(p<0.05)$ nificant at only one time point, and a reciprocal decline in insulin levels (Fig. 2). Glucagon secretion rate rose from $2.26 \pm 0.28 \mathrm{ng} / \mathrm{min}$ to $2.63 \pm 0.47 \mathrm{ng} / \mathrm{min}$ (NS), and declined to $2.02 \pm 0.29 \mathrm{ng} / \mathrm{min}(p<0.05)$ upon restoration of the glucose level to $100 \mathrm{mg} / \mathrm{dl}$ (Table 1D). Insulin declined significantly during the glucopenic period (Fig. 2). During perfusion of antiinsulin serum the glucagon secretion rate rose significantly from $9.63 \pm$ $0.66 \mathrm{ng} / \mathrm{min}$ to $12.3 \pm 0.94 \mathrm{ng} / \mathrm{min}(p<0.01)$. The mean increase in secretion rate was $2.66 \pm 0.60 \mathrm{ng} / \mathrm{min} \mathrm{com}-$ pared to an increase of $0.38 \pm 0.21 \mathrm{ng} / \mathrm{min}$ in the control experiments with nonimmune serum (Table $1 \mathrm{D})$. When glucose concentration was maintained at $100 \mathrm{mg} / \mathrm{dl}$ throughout the experiment (Table $1 \mathrm{~A}$ ), there was no increase in glucagon at the comparable time interval during antiserum perfusion.

\section{Discussion}

Samols and coworkers in 1965 first identified the glucagon suppressing effect of insulin [14], and postulated a regulatory role for insulin upon the alpha cell response to glycaemic change $[15,16]$. According to the hypothesis, the suppression of glucagon by hyperglycaemia and its stimulation by hypoglycaemia might at least in part be mediated by glucose induced changes in insulin secretion, a construct that would account for the loss of these alpha cell responses following destruction of $B$ cells [2-5].

Against this hypothesis are two pieces of evidence suggesting that alpha cells can respond to a change in glucose concentration independently of insulin and $\mathrm{B}$ cells. In insulin-deprived dogs with alloxan-induced deficiency of endogenous insulin, glucagon can be sup- 
pressed normally by glucose provided that hyperglycaemia is first eliminated [6]; in Type I diabetic patients the glucagon response to insulin-induced hypoglycaemia remains normal for the first 15 months following destruction of the B cells [17]. However, since the foregoing evidence was obtained in diabetic islets in which B cells were destroyed by cytoxic or immune-mediated events and which had been chronically exposed to hyperglycaemia, they may not be relevant to the physiologic role of insulin in normal islets that have never been damaged or exposed to a diabetic metabolic milieu. Prolonged hyperglycaemia itself may impair islet cell function [6-8]. To dissociate the effects of insulin deficiency from the effects of concomitant hyperglycaemia, the influence of an acute deficiency of endogenous insulin upon the alpha cell response to glycaemic change was examined in islets from normal rats without antecedent hyperglycaemic experience. The prompt rise in glucagon induced by antiserum perfusion and its fall soon after its termination was construed as evidence that the antiserum had lowered the insulin concentration within the islet to below the level required to restrain glucagon secretion [1]. Measurements of free insulin in antiserum-containing pancreatic effluent could not be made because of the persistence of antibodies despite repeated extractions. However, aliquots of the antiserum-containing perfusate employed in these studies (Miles-Yeda GP-29) are known to neutralize $100 \%$ of $20 \mathrm{mU} / \mathrm{ml}$ of insulin [1], the estimated concentration of insulin within the islet circulation [18], during a 1-min incubation at $37^{\circ}$ in simulation of the conditions of antiserum contact with endogenous insulin during its transit through the pancreas [1]. Moreover, since electronmicroscopic examination of pancreas obtained after perfusion with antiserum at a constant $100 \mathrm{mg} / \mathrm{dl}$ glucose concentration (not shown) revealed no B cell degranulation, it is likely that in this constant metabolic milieu antiserum does not cause a compensatory increase in insulin secretion that might exceed the neutralizing capacity of the perfusate. Therefore, its neutralizing effect was probably constant throughout the experiment.

Perfusion of antiserum blocked glucagon suppression by a $30 \mathrm{mg} / \mathrm{dl}$ and $80 \mathrm{mg} / \mathrm{dl}$ increase in glucose but failed to prevent the stimulation of glucagon secretion by a $20 \mathrm{mg} / \mathrm{dl}$ decrease in glucose. Instead, the glucagon response seemed greater, making it unlikely that insulin played an obligatory role in the alpha cell response to glucopenia. This conclusion is consistent with other in vivo studies [17]. It is also unlikely that norepinephrine, which mediates at least $70 \%$ of the response of the alpha cell to more profound glucopenia [10], was the mediator, since in the present experiments glucopenia was well within the physiologic range in which the role of norepinephrine is thought to be minimal [10]. The marked exaggeration of the glucagon response to glucopenia during antiserum perfusion may therefore point to potentiation of a mediator other than norepinephrine or insulin.

A second interpretation of these data is that by eliminating a constant restraining influence upon alpha cells the antiserum simply shifted alpha cell responsiveness in a direction that sensitized them to stimulation and desensitized them to suppression. This is consistent with studies in Type I diabetic patients who demonstrate an exaggerated glucagon response to stimuli such as arginine [2] and its correction by insulin [19, 20]. However, it is not consistent with the demonstration that glucagon is suppressed by glucose in vivo in the complete absence of insulin in insulin-deprived alloxan-diabetic dogs rendered chronically hypoglycaemic by phloridzin pretreatment [6]. The latter finding suggests that alpha cells can be suppressed by glucose independently of insulin and cells. It is not known if the apparent conflict in findings is due to species difference, the higher baseline glucose concentration of the in vitro studies $(100 \mathrm{mg} / \mathrm{dl} \mathrm{vs}, \sim 60 \mathrm{mg} / \mathrm{dl})$, or the many other experimental and anatomical differences between the two preparations, including the lack of cells in the alloxan-diabetic dog islets and/or the severence of neural connections in the isolated rat pancreas.

In the experiments depicted in Figures $1 \mathrm{~B}$ and 2, a paradoxical single point rise in glucagon was observed immediately upon termination of the perfusion of antiinsulin serum. This phenomenon had been observed earlier [1], and is probably due to norepinephrine release, which has been reported to be caused by insulin $[21,22]$. Coperfusion of phentolamine and propranolol throughout perfusion experiments using anti-insulin antiserum abolished the post-antiserum rise in glucagon (Maruyama, unpublished observation).

Acknowledgments. The authors thank the following persons for their expert technical assistance: H.Gibson, V.Harris, K. McCorkle, L. Peace and D.Sandlin. This work supported by Veterans Administration Institutional Research Support Grant 549-8000-01, National Institutes of Health grant AM-02700-25, and Swiss National Science Foundation grant 3.460 .83 .

\section{References}

1. Maruyama H, Hisatomi A, Orci L, Grodsky GM, Unger RH (1984) Insulin within islets is a physiologic glucagon release inhibitor. J Clin Invest 74: 2296-2299

2. Unger RH, Aguilar-Parada E, Muller WA, Eisentraut AM (1970) Studies of pancreatic alpha cell function in normal and diabetic subjects. J Clin Invest 49:837-848

3. Muller WA, Faloona GR, Aguilar-Parada E, Unger RH (1970) Abnormal alpha cell function in diabetes. Response to carbohydrate and protein ingestion. N Engl J Med 283: 109-115

4. Muller WA, Faloona GR, Unger RH (1971) The effect of experimental insulin deficiency on glucagon secretion. J Clin Invest 50: 1992-1999

5. Gerich J, Langlois M, Noacco C, Karam J, Forsham P (1973) Lack of a glucagon response to hypoglycaemia in diabetes: Evidence for an intrinsic pancreatic alpha cell defect. Science 182: 171-173

6. Starke A, Grundy S, McGarry JD, Unger RH (1985) Correction of hyperglycaemia by inducing renal malabsorption of glucose res- 
tores the glucagon response to glucose in insulin-deficient dogs: Implications for human diabetes. Proc Natl Acad Sci USA 82: 1544-1546

7. Hermansen K, Schmitz O, Orskov H (1985) Reversal of D- and Acell insensitivity to glucose in alloxan-diabetic dogs by treatment with the artificial beta cell (Biostator). Diabetes 34: 260-266

8. Dimitriadis G, Cryer P, Gerich JE (1985) Prolonged hyperglycaemia during infusion of glucose and somatostatin impairs pancreatic A- and B-Cell responses to decrements in plasma glucose in normal man: evidence for induction of altered sensitivity to glucose. Diabetologia 28: 63-69

9. Grodsky GM, Fanska RE (1975) The in vitro perfused pancreas. Methods Enzymol 39:364-372

10. Hisatomi A, Maruyama H, Orci L, Vasko M, Unger RH (1985) Adrenergically mediated intrapancreatic control of the glucagon response in the isolated rat pancreas. J Clin Invest 75: 420-426

11. Harris V, Faloona GR, Unger RH (1979) Glucagon. In: Jaffe BM, Behrman HR (eds) Methods of hormone radioimmunoassay. Academic, New York, pp 643-656

12. Herbert V, Lau KS, Gottlieb CW, Bleicher SJ (1965) Coated charcoal immunoassay of insulin. J Clin Endocrinol Metab 25: 1375-1384

13. Yalow RS, Berson SA (1960) Immunoassay of endogenous plasma insulin in man. J Clin Invest 39: 1157-1175

14. Samols E, Tyler J, Marks V (1972) Glucagon-insulin interrelationships. In: Lefebvre PJ, Unger RH (eds) Glucagon. Molecular physiology, clinical and therapeutic implications. Pergamon Oxford, $p p$ 151-174

15. Samols E, Weir GC, Bonner-Weir S (1983) Intraislet insulin-glucagon-somatostatin relationships. In: Lefebvre PJ (ed) Glucagon II. Springer, Berlin Heidelberg New York Tokyo, pp 133-174

16. Unger RH (1983) Insulin-glucagon relationships in the defense against hypoglycaemia. Diabetes 32: 575-583
17. Bolli G, DeFeo P, Perriello G, DeCosmo S, Compagnucci P, Santeusanio F, Brunetti P, Unger RH (1984) Mechanisms of glucagon secretion during insulin-induced hypoglycaemia in man. Role of the beta cell and arterial hyperinsulinemia. $J$ Clin Invest 73 : 917-922

18. Honey RN, Fallon MB, Weir GC (1980) Effects of exogenous insulin, glucagon and somatostatin on islet hormone secretion in the perfused chicken pancreas. Metabolism 29: 1242-1246

19. Raskin P, Aydin L, Unger RH (1976) Effect of insulin on the exaggerated glucagon response to arginine stimulation in diabetes mellitus. Diabetes 25: 227-229

20. Gerich J, Lorenzi M, Tsalikian E, Bohanon M, Noacco C, Karam J, Forsham $P$ (1976) Effects of acute insulin withdrawal and administration on plasma glucagon response to intravenous arginine and insulin-dependent diabetic subjects. Diabetes 25: 955-960

21. Rowe JW, Young JB, Minaker KL, Stevens AL, Pallotta J, Landsberg L (1981) Effect of insulin and glucose infusions on sympathetic nervous system activity in normal man. Diabetes 30 : 219-225

22. Christensen NJ (1983) Acute effects of insulin on cardiovascular function and noradrenaline uptake and release. Diabetologia 25 : $377-381$

Received: 21 June 1985

and in revised form: 29 September 1985

Dr. Roger H. Unger

Veterans Administration Medical Center

4500 South Lancaster Road

Dallas, Texas 75216

USA 